\title{
Association of Hashimoto's Thyroiditis and Graves' Disease: A Case Report and Review of the Literature
}

\author{
Nafissatou Diagne*, Maimouna Sow, Atoumane Faye, Awa Cheikh Ndao, Mouhamed Dieng, \\ Boundia Djiba, Baidy Sy Kane, Abdoulaye Pouye
}

CHU Aristide Le Dantec de Dakar, Dakar, Senegal

Email: *nafissatoud@hotmail.com

How to cite this paper: Diagne, N., Sow, M., Faye, A., Ndao, A.C., Dieng, M., Djiba, B., Kane, B.S. and Pouye, A. (2021) Association of Hashimoto's Thyroiditis and Graves' Disease: A Case Report and Review of the Literature. Case Reports in Clinical Medicine, 10, 303-307.

https://doi.org/10.4236/crcm.2021.1010038

Received: September 20, 2021

Accepted: October 18, 2021

Published: October 21, 2021

Copyright $\odot 2021$ by author(s) and Scientific Research Publishing Inc. This work is licensed under the Creative Commons Attribution International License (CC BY 4.0).

http://creativecommons.org/licenses/by/4.0/

\begin{abstract}
Graves' disease and Hashimoto's thyroiditis are two common autoimmune diseases. Their association with other autoimmune diseases is not exceptional. However, the co-occurrence of these two diseases is not often described. In this case, report, we describe the observation of a patient who had long been followed for exophthalmos and pretibial myxedema as a sign of thyrotoxicosis. Examination of this patient revealed a clinical picture of clinical and biological hypothyroidism related to Hashimoto's thyroiditis. This case had made it possible to retain an association between Hashimoto's thyroiditis and basedowdisease, which is rarely described. This observation underscores the importance of monitoring these patients with autoimmune disease systematically even if there is no clinical manifestation.
\end{abstract}

\section{Keywords}

Hashimoto, Graves’ Disease, Antibodies, Dakar

\section{Introduction}

Graves' disease and Hashimoto's thyroiditis are the two most common autoimmune thyroid diseases [1]. The first one is related to the presence of autoantibodies that abnormally stimulate the thyroid stimulating hormone (TSH) receptors present in the thyroid gland, causing its hyperfunction [2]. The second is characterised by progressive destruction of thyroid cells with the presence of antibodies, the most specific of which is the anti-thyroperoxidase (TPO) antibodies, evidence of autoimmunity [2].

The combination of these two conditions is unusual. 
We report the case of a patient with Hashimoto's thyroiditis but also with clinical and immunological signs specific to Graves' disease.

\section{Observation}

The patient was 47 years old and presented with generalized oedema for 8 months. She did not report any particular pathological history.

She had an acquired exophthalmia for several years, bilateral, painless, reducible, without associated goitre (Figure 1). She had never presented clinical and laboratory signs of hyperthyroidism. Previous thyroid hormone results were normal.

Her current clinical examination revealed a myxoedematous syndrome with facial puffiness, hoarseness of voice and elastic oedema of the lower limbs (Figure 2).

This symptomatology was associated with marked physical asthenia and chronic constipation. She had a blood pressure of $120 / 60 \mathrm{mmHg}$, a weight of $80 \mathrm{~kg}$ and a heart rate of 60 cycles/minute.

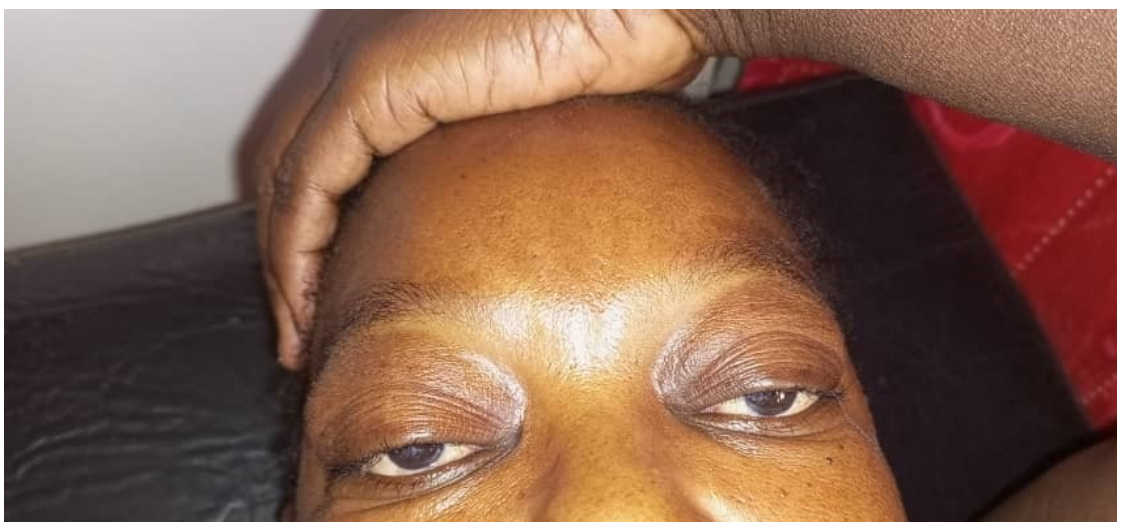

Figure 1. Bilateral exophthalmia.

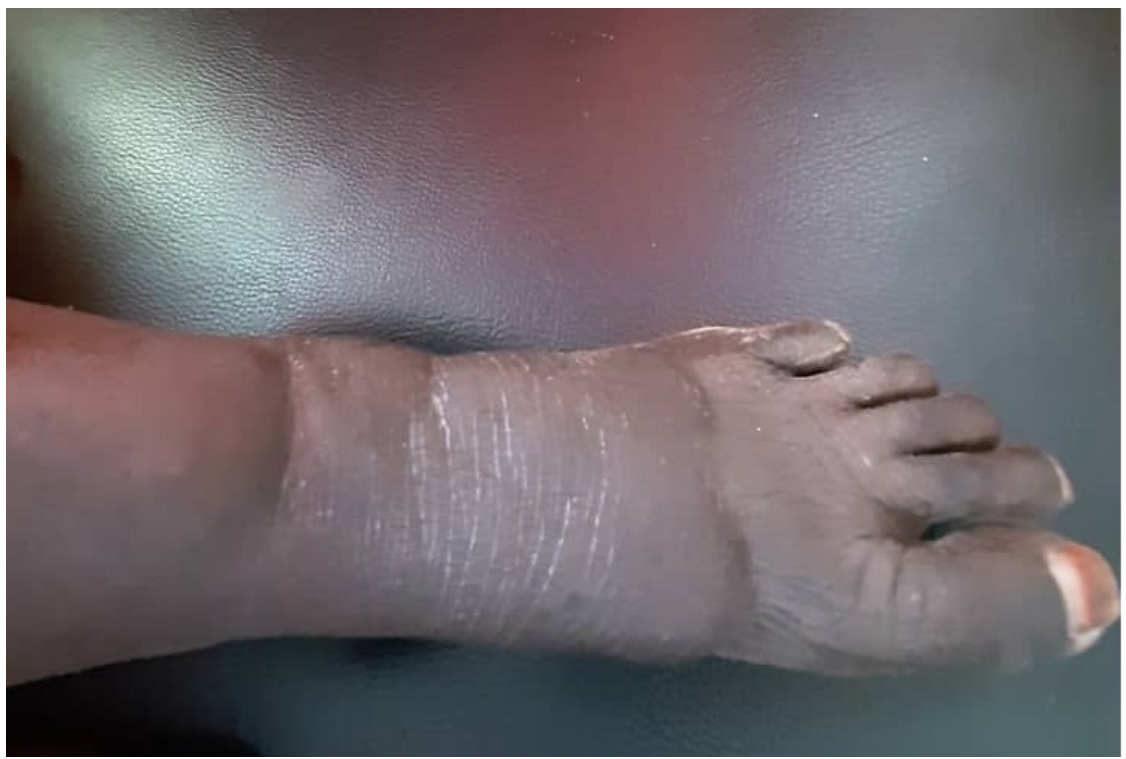

Figure 2. Myxoedema of the lower limb. 
On biological examination, an elevated TSH level of $18.7 \mu \mathrm{IU} / \mathrm{ml}$ (norms 0.35 4.94) was noted. Anti-TPO antibodies were positive at a level above $1000 \mathrm{IU} / \mathrm{ml}$.

The diagnosis of Hashimoto's thyroiditis was made. Treatment with L-thyroxine $50 \mathrm{ug} / \mathrm{d}$ was initiated.

In addition, the TSH receptor antibody test performed for this exophthalmia was positive at $2.8 \mathrm{IU} / \mathrm{L}$ (standard $<1.75$ ).

Hashimoto's thyroiditis associated with Graves' disease was diagnosed.

The clinical evolution was favourable, and the patient is regularly attended.

\section{Discussion}

In this paper we describe an association between two specific autoimmune diseases of the thyroid gland.

Graves' disease and Hashimoto's thyroiditis are two organ-specific autoimmune diseases. Graves' disease is the most common cause of hyperthyroidism [3]. A recent study in our country shows that hyperthyroidism accounts for about $18 \%$ of outpatient visits and $72 \%$ of these cases were related to Graves' disease [4]. Similarly, Hashimoto's thyroiditis is the most common cause of hypothyroidism. Its prevalence is estimated to be around 8 per 1000 population according to a study [2]. These two diseases are more frequent in women than in men, with a sex ratio varying from $1 / 5$ to $1 / 10$ [1].

The disease is characterised by a variable combination of thyrotoxicosis, homogeneous vascular goitreous, exophthalmia and pretibial myxoedema.

Hashimoto's thyroiditis has a variable clinical presentation. It may begin with a phase of hyperthyroidism called Hashitoxicosis followed by a phase of euthyroidism before the onset of permanent hypothyroidism [2].

Autoimmune diseases are unique in that they are frequently associated due to the common dysimmune environment. Thus, autoimmune thyroiditis can be associated with other autoimmune diseases [5]. However, the association between autoimmune thyroid diseases is rarely described [3].

A few case reports have indicated the sequential occurrence of these diseases. In these cases, Hashimoto's thyroiditis followed treated Graves' disease [6] [7].

A few cases of Graves' disease occurring on Hashimoto's hypothyroidism have been reported [8] [9].

In our case, the chronology of the signs suggests that basedow's disease preceded the hypothyroidism. Indeed, the acquired exopthalmia has been evolving for several years.

TPO antibody positivity is possible in Graves' disease [10] [11]. This could suggest the possibility of co-existence of these two pathologies. In our case, these antibodies were found at high levels and were associated with clinical signs of hypothyroidism.

In this sense, a study reported an observation in which Graves' disease was associated with both specific antibodies and anti-TPO antibodies. Furthermore, in this observation, histology of the gland after thyroidectomy showed features 
of both Graves' disease and Hashimoto's thyroiditis [3].

This association between Graves' disease and Hashimoto's is not accidental. It can be explained by a common pathogenesis on certain points. Indeed, both diseases occur as a result of genetic and environmental factors leading to damage to thyroid cells with the production of autoantigens responsible for an immune reaction. An imbalance in the TH1/TH2 balance in favour of the former activates cellular immunity responsible for the destruction of the thyroid cells at the origin of Hashimoto's thyroiditis. A predominance of TH2 would rather activate humoral immunity with the production of antibodies to the TSH receptor, which is the cause of Graves' disease [1]. The immune reaction in Graves' disease leading to the production of anti-THS receptor antibodies may also lead to the production of anti-TPO and anti-thyreoglobulin antibodies explaining the possible presence of the latter antibodies in this disease [12].

The exophthalmos present in our patient is an important sign and very suggestive of Graves' disease as it is directly related to TSH receptor antibodies. Indeed, these receptors are present both on thyroid cells and on orbital fibroblasts. Antibodies to these receptors are present in $100 \%$ of patients with dysthyroid orbitopathy [13].

\section{Conclusion}

The association between two autoimmune thyroid diseases is rarely described. However, a pathophysiological explanation for this association may be possible. We presented this case of an association of Graves' disease and Hashimoto's thyroiditis in a patient with clinical manifestations and immunological markers of both diseases. This observation confirms the often possible association between two autoimmune diseases, whether organ specific or non-specific, and the importance of regular monitoring in the event of an autoimmune disease.

\section{Conflicts of Interest}

The authors declare no conflicts of interest regarding the publication of this paper.

\section{References}

[1] Dong, Y.H. and Fu, D.G. (2014) Autoimmune Thyroid Disease: Mechanism, Genetics and Current Knowledge. European Review for Medical and Pharmacological Sciences, 18, 3611-3618.

[2] Caturegli, P., De Remigis, A. and Rose, N.R. (2014) Hashimoto Thyroiditis: Clinical and Diagnostic Criteria. Autoimmunity Reviews, 13, 391-397. https://doi.org/10.1016/j.autrev.2014.01.007

[3] Horiya, M., Anno, T., Kawasaki, F., Iwamoto, Y., Irie, S., Monobe, Y., Tomoda, K., Kaku, K., Nakanishi, N. and Kaneto, H. (2020) Basedow's Disease with Associated Features of Hashimoto's Thyroiditis Based on Histopathological Findings. BMC Endocrine Disorders, 20, Article No. 120. https://doi.org/10.1186/s12902-020-00602-8 
[4] Diagne, N., Sow, M., Faye, A., Ndao, A.C.,Dieng, M., Kane, B.S., Djiba, B. and Pouye, A. (2016) Aspects épidémiologique, clinique, thérapeutique et évolutif de la maladie de Basedow en Médecine Interne au CHU Le Dantec Dakar (Sénégal). Pan African Medical Journal, 25, 6. https://doi.org/10.11604/pamj.2016.25.6.7868

[5] Diagne, N., Ndao, A.C., Faye, A., Dia, D.G., Sow, M., Djiba, B., Kane, B.S., Dieng, M. and Pouye, A. (2020) Epidémiologie descriptive de l'association de dysthyroïdies auto-immunes avec d'autres affections auto-immunes dans un service de Médecine Interne au sud du Sahara. RAFMI, 7, 16-21.

[6] Melki, A., Oueslati, I., Kilani, M.O., Mchirgui, N., Khiari, K. and Abdallah, N. (2014) Maladie de Basedow suivie d'une thyroïdite de Hashimoto chez une même patiente. Annales d Endocrinologie, 75, 489. https://doi.org/10.1016/j.ando.2014.07.744

[7] Umar, H., Muallima, N., Adam, J.M.F. and Sanusi, H. (2010) Hashimoto's Thyroiditis Following Graves' Disease. Acta Medica Indonesiana, 42, 31-35.

[8] Mehmet, A., Binnetolu, E., Hacer, S., TekeliZ, U.F. and Ukinç, K. (2013) Graves' Disease Associated with Alopecia Areata Developing after Hashimoto's Thyroiditis. Journal of Nippon Medical School, 80, 467-469. https://doi.org/10.1272/jnms.80.467

[9] Ekpebegh, C., Elmezughi, K. and Mtingi, L. (2019) Graves' Disease Following Hypothyroidism Due to Hashimoto's Thyroiditis in a Black South African Lady: A Case Report. The Pan African Medical Journal, 32, 186. https://doi.org/10.11604/pamj.2019.32.186.18713

[10] Zeitlin, A.A., Simmonds, M.J. and Gough, S.C. (2008) Genetic Developments in Autoimmune Thyroid Disease: An Evolutionary Process. Clinical Endocrinology, 68, 671-682. https://doi.org/10.1111/j.1365-2265.2007.03075.x

[11] Bliddal, S., Nielsen, C.H. and Feldt-Rasmussen, U. (2017) Recent Advances in Understanding Autoimmune Thyroid Disease: The Tallest Tree in the Forest of Polyautoimmunity. F1000Research, 6, 1776. https://doi.org/10.12688/f1000research.11535.1

[12] McLachlan, S.M., Nagayama, Y., Pichurin, P.N., Mizutori, Y., Chen, C.R., Misharin, A., Aliesky, H.A. and Rapoport, B. (2007) The Link between Graves' Disease and Hashimoto's Thyroiditis: A Role for Regulatory T Cells. Endocrinology, 148, 5724-5733. https://doi.org/10.1210/en.2007-1024

[13] Morax, S. and Badelon, I. (2009) L'exophtalmie Basedowienne. Journal Français d' Ophtalmologie, 32, 589-599. https://doi.org/10.1016/j.jfo.2009.09.001 